\title{
Chapter 12 Silvopastoral Systems as a Tool for Territorial Sustainability and Biodiversity
}

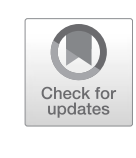

\author{
F. Torres-Manso, A. A. Marta-Costa, M. Castro, and L. Tibério
}

\begin{abstract}
Rural and livestock population evolution in the inner north of Portugal has demonstrated a great regression with consequences for environment and nature conservation. In this context, and taking into account that pastoral activity has shaped the natural areas of mountain territories since its beginning and that territories are currently part of Natura 2000 network, rethinking the importance of such activity has become vital. The constraints affecting daily tasks performed by shepherds and livestock breeders as well as the installed social segregation are a strong limitation. However, current research developed in the context of nature conservation has demonstrated the importance of the landscape mosaic promoted by grazing in the preservation of priority habitats. In this way, it is urgent to assess the issue of shepherds and livestock breeders' image in terms of their roles, relationships and concerns, as well as to assess pastoralism socioeconomics in regard to selfconsumption, market and rural self-sufficiency. In this perspective, this work presents an analysis of the adaptation of grazing to current times, perceiving its limitations and success potential.
\end{abstract}

Keywords Grazing $\cdot$ Natura network $\cdot$ Shepherds $\cdot$ Socioeconomics

\footnotetext{
F. Torres-Manso

Department of Forest and Landscape; Centre for Transdisciplinary Development Studies, University of Trás-os-Montes e Alto Douro, Vila Real, Portugal
}

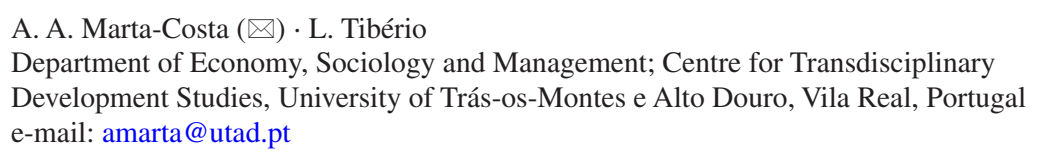




\section{Introduction}

Since 1955 rural and livestock population show a decreasing evolution in Portugal (Torres-Manso et al. 2014). Such phenomenon, demonstrating the problem of rural abandonment in marginal areas, has originated an increase in moorlands and the development of large-scale shrub vegetation, therefore promoting combustible biomass accumulation which is intensely correlated with fire propagation. Several authors (Almeida and Moura 1992; Mather and Pereira 2006; Ruiz-Mirazo and Robles 2012; Mancilla-Leytón et al. 2013) have pointed out the existence of larger burnt areas in municipalities with a higher immigration degree, therefore highlighting that the relation between demography and fire incidence is stronger for forest stands than for rangelands. Consequently, there is an increase of burnt areas in regions with population loss, which are dominant in regions with the larger forest stand areas when compared with mountain regions, in which shrub areas are partitioned by meadows and small oakwoods, therefore promoting biodiversity (TorresManso et al. 2014). Extensive pastoralism remains in the latter landscape context, and its non-existence would jeopardise the heterogeneity of several priority habitats of Natura 2000 network. Current research in the scope of nature conservation has demonstrated the importance of the landscape mosaic promoted by grazing in the mentioned habitat conservation (Papanastasis et al. 1998; Mouquet et al. 2005; Whitehead et al. 2005; Pereira 2006).

The tendency for the decrease of pastoral activity has contributed to raise new questions regarding pastoralism relevance as an environmentally important socioeconomic activity. In the Portuguese mountain and/or inner areas, there are known conditions of isolation, the lack of accessibility and logistic infrastructures. Urban areas are therefore more attractive with expectations of a different, modern and socially prestigious life, with a higher availability of material assets. Likewise, it is known that many times, abandonment of rural areas is not only the outcome of economic issues but also of the social discredit of rural works. For some, isolation, rurality and tradition are associated with lagging or inexistent development and even to a reversal on the production process. Pastoral activity is still based on traditional ancient know-how and practices that not always follow commercial and financial market evolution. Thus, rethinking the issues of shepherds and livestock breeders' image in terms of their roles, relationships and concerns becomes crucial, as well as rethinking pastoralism socioeconomics regarding self-consumption, market and rural self-sufficiency.

In this perspective, a set of approaches have been made in the scope of Natura 2000 network and focused in mountain territories of the inner north of Portugal, with the goal of understanding contextual issues concerning extensive grazing, shepherd activity and its importance for nature conservation. In this sense, the framing of the Sites of Community Importance (SCI) which were the focus of the mentioned studies and the respective extensive grazing systems is made in the following section. Section 3 describes the relationship between the systems and shepherd 
activity, pointing out its constraints and highlighting its role in the scope of nature conservation. The analysis of socioeconomic sustainability of grazing systems and its current evolution and gradual adaptation to reality is presented in Sect. 4.

\section{Sites of Community Importance in the North Interior of Portugal and Extensive Grazing Systems}

Europe's most important international legal agreements for protected areas are the UN Convention on Biological Diversity and the EU's Birds (79/409/EEC) and Habitats (92/43/EEC) Directives (EEA 2012). These two nature directives are at the core of the continent-wide biodiversity conservation strategy, guided by the European Commission and implemented by the member states (European Commission 2014a and 2014b in Kukkala et al. 2016), and have established the Natura 2000 network of protected areas over Europe. Currently, there are more than 27,000 SCI, covering 18\% of EU's land area (EEA 2012). These protected areas encompass a wide variety of natural environments, from the Black Sea shoreline to Alpine meadows and from arid shrubland to rich pasture (EEA 2012). In Portugal, Natura network comprises 61 sites and covers about 1,600,000 ha, i.e. about $20 \%$ of Portuguese mainland territory.

A great part of these protected areas in Mediterranean highlands of the north of Portugal underwent profound changes on their demographic structure, social organisation and usage of space by humans, since the middle of the twentieth century. These abandonment processes were preceded by an intense human intervention over the centuries, particularly those connected with pastoral activities. Because of this relationship, several grazing systems have been developed. Some of them are disappearing rapidly, but there are still fine examples, like the mountain regions of Portugal's inner.

This chapter addresses five mountainous SCI, located in the North inland of Portugal (Fig. 12.1). Regarding low population density and grazing systems, these SCI are very similar however their ecological differences. Specifically, it will focus on the "Douro Internacional" (plateau nature) and the "Montesinho-Nogueira", both with climatic continentally influence; the "Morais-Azibo" with a pronounced Mediterranean character; and the "Alvão-Marão" and "Serra de Montemuro", which present marked Atlantic nature.

The mountainous areas of northern Portugal overlap with regions tending to be depressed by adverse edaphoclimatic conditions and marginal rural areas, usually peripheral and difficult to access, either by orography or inland conditions. However, in these mountain complexes, the singular topography, soil heterogeneity and the range of slopes are factors that promote the high diversity of habitats and silvopastoral systems. Mountain pastures are an essential element in the creation of a number of mountain ecosystem services on which human wellbeing depends (Aguiar et al. 2015). Thus, water quality, landscape, biodiversity shelter, forest products, 


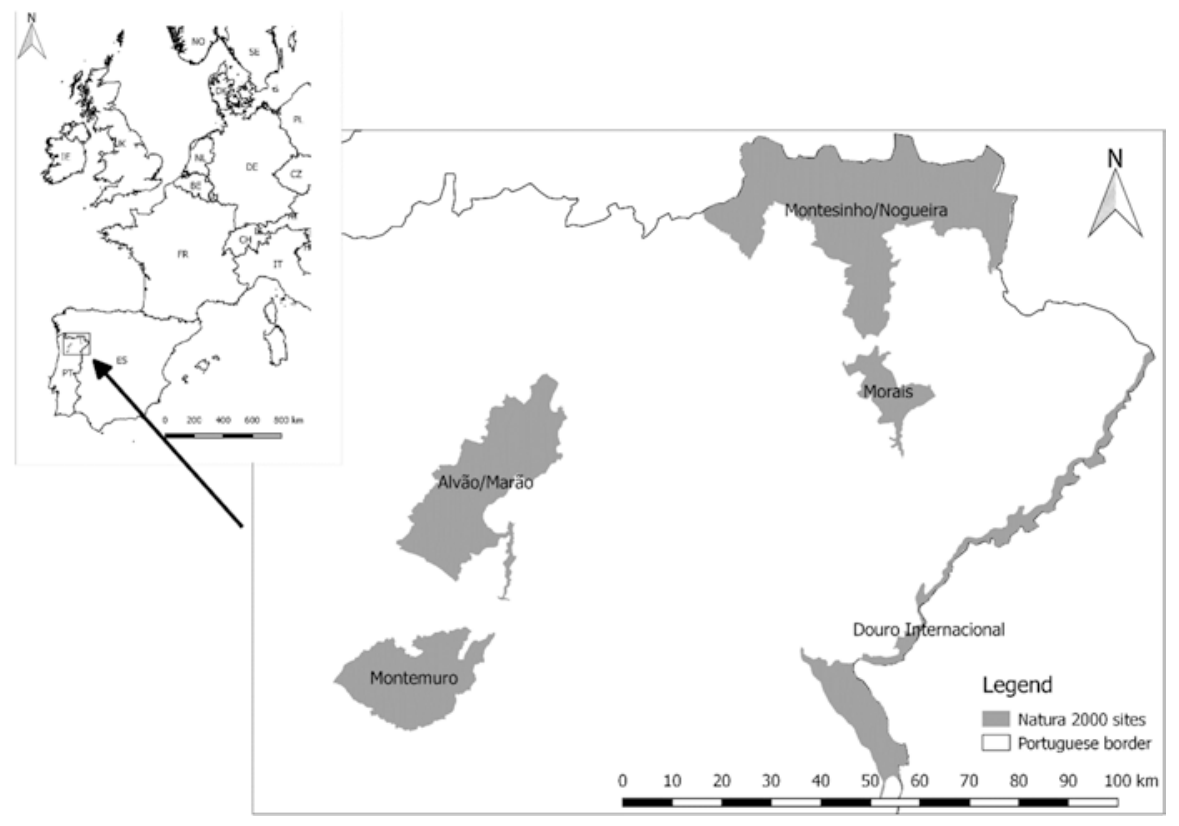

Fig. 12.1 Natura 2000 network studied SCI in the north of Portugal (Source: Own elaboration)

agriculture products and quality meat are examples of regulation and supply services. Poor soil suitability and altitude, both agricultural production limiting factors, allow little more than the practice of extensive shepherding which constitutes a primordial human activity from time immemorial.

Extensive grazing systems are normally associated with the constant demand for intrinsic regulations, e.g. low consumption of agronomic and/or veterinary inputs, use of native and rustic breeds, and use of trees and shrub species as fodder for animals, among others (Castro 2016). The nature of extensive systems relies on their resilience, i.e. in a demand for a proper production level that uses the least possible external resources, with special emphasis on the adaptation and farming of native breeds - a central element of extensive production systems. Likewise, it is worth pointing out that these systems are also an integral part of the territory's historic and cultural heritage (Telo da Gama 2004). Usually, there is a low animal density per area unit, and animal feeding is based on natural pasture. Pastures vary significantly over the year, both in availability and nutritional terms. Also, grazing activity is a unique exploitation mean for extended land areas, as it allows the concentration of scattered primary production and its conversion into animal protein sources. In these regions, small ruminants and beef cattle of native breeds, complemented by annual rainfed crops, are relevant and are the foundation of economic activity for these territories, as they often represent the last chance of landscape use.

In the larger part of these mountain regions, small ruminant production is based in the shepherding system (Castro et al. 2000), characterised by the daily travels of 
the flock, wandering through lands with no agricultural use, with feeding being based in a complex network of concentric paths that lead to the places where the flock stays overnight (Castro et al. 2003). Shepherding circuit planning is the outcome of an assessment of available land made by the shepherd in which he considers environmental and logistic constraints (Castro and Castro 2003). In these systems, animal grazing is made only in the territory of the parish or in its surroundings. The animals are kept in stables at night, and its location is a determinant factor for the definition of grazing itineraries, due to animal physical limitations.

Despite the current decline of pastoral activity, it is also worth highlighting the important meaning of extended marginal areas in shepherding, fundamentally, in route shepherding. Most of these areas are frequently community areas where there are low shrubs formed by heath (Erica spp.), Pterospartium tridentatum, gorse (Ulex spp.) and Halimium spp. (Torres-Manso 2015). These community areas, also designated as "common lands", can be used by any resident or breeder of the group of civil parishes to which the respective common properties belong. Over time, common lands became an important resource in terms of flock grazing, as community use has always favoured shepherding (Pinto 1999).

Depending on species demands and considering a scale of variation between sheep, goats and cattle, one can identify systems that predominantly use natural food resources, others that integrate agricultural by-products, stubble and fallow lands, and others associated with forage crops, focusing on animal feeding. In the case of cattle, the grazing system is more unmoving than in small ruminant, and it focuses on grasslands associated with other fodder crops which vary according to ecological conditions of the site. In the region, there are two broad types of grasslands which can be related to geology and soil type and, to a lesser degree, altitude and climatic conditions. Acidic grasslands normally occur on lighter sandy soils or in upland regions. Neutral grasslands occur on clay loams or alluvial floodplains, mostly lowland but some in upland situations. Concerning management types and water availability can occur hay-meadows or pasture and dry or wet meadows. In the Douro Internacional and Morais-Azibo SCI, the meadows tend to be less productive than in the Montesinho-Nogueira, Alvão-Marão and Montemuro SCI, due the drier climatic conditions associated with poor soil suitability.

Meadows are ecosystems with a special conservation status in Portugal, and their management is made in a very peculiar way that is also essential for their protection and for their potential productive in grass and hay. Four types can be distinguished, in function of water availability and management by the herders: dry hay meadows, dry pastures, wet hay meadows and mowing meadows.

Dry hay meadows are reserved between March/April and June (for highlands usually in late July), when they are harvested, and then they are grazed if there is pasture. Some of the dry meadows (dry pastures) are used only for grazing, which are usually those less wet and consequently less productive, sometimes designated as pastigueiro, depending on hay reserved and livestock farming demands (Sousa and Sanchéz 2009). Wet meadows are usually also undergoing a mixed-use regime, generally with two cuts, the first for grass and the second for hay (Sousa and Sanchéz 2009). Others, abundant in water and located near the parish, are destined only for 
Table 12.1 Seasonal daily grazing durations and distances walked by goats and sheep (mean \pm S.E.M.). Different letters indicate significant differences between seasons for the same animal species

\begin{tabular}{l|l|l|l|l}
\hline \multirow{2}{*}{} & \multicolumn{2}{|l|}{ Daily grazing duration $\left(\mathrm{min}^{-1}\right)$} & \multicolumn{2}{l}{ Grazing itinerary length $\left(\mathrm{km} \mathrm{d}^{-1}\right)$} \\
\cline { 2 - 5 } & Goats & Sheep & Goats & Sheep \\
\hline Autumn & $8.8 \mathrm{a} \pm 2.55$ & $9.4 \pm 1.75$ & $7.02 \mathrm{a} \pm 0.83$ & $10.1 \mathrm{a} \pm 0.58$ \\
\hline Winter & $5.8 \mathrm{~b} \pm 1.25$ & $6.7 \mathrm{~b} \pm 1.25$ & $6.14 \mathrm{a} \pm 1.59$ & $5.07 \mathrm{~b} \pm 2.68$ \\
\hline Spring & $6.5 \mathrm{~b} \pm 0.72$ & $8.2 \mathrm{ab} \pm 1.9$ & $5.16 \mathrm{a} \pm 0.85$ & $4.00 \mathrm{c} \pm 1.84$ \\
\hline Summer & $6.3 \mathrm{~b} \pm 1.98$ & $9.4 \mathrm{a} \pm 1.85$ & $6.13 \mathrm{a} \pm 0.89$ & $6.27 \mathrm{~b} \pm 3.48$ \\
\hline
\end{tabular}

Source: Castro and Fernández-Núñez (2016)

grass, therefore being designated as mowing meadows (Teles 1970; Portela 1988). These provide forage for complement cattle feeding when hay meadow which is shut off from grazing livestock. In the plateau of Miranda do Douro (Douro Internacional SCI), the most common forage is corn, unripe rye and oats, hay, usually ad libitum, and cereals (rye grain) only for exceptional feeding needs (cattle breeding and raising and cows postpartum) (Sousa and Sanchéz 2009).

Meadow lands are usually private property and are normally located near the village. Typically, the number of beef cattle in farms depends on the area of the private meadows. Shrub biomass consumption is significant, which, associated with goat headcounts, extends the fire reoccurrence cycle. On the other hand, common lands are in more remote areas and are used during summer, when lowland resources are scarce and daylight hours are sufficient to allow cattle to go to the mountains and return daily. Thus, beef cattle feeding in these areas is based on different quality pasture that depends on the season, with animals being supplemented with hay ad libitum during winter and with corn and rye flour being fed only to calves.

As for small ruminants, grazing itineraries are limited by natural factors like the daylight time, maximum and minimum temperatures, stable location and resource availability (Castro et al. 2009; Castro 2004). Resource availability and spatial distribution are also important factors, though not decisive for the itineraries, as the said aspects affect essentially the distance, given that animals take longer walks when food is scarce and smaller walks in the remaining cases. Table 12.1 shows seasonal variation of itinerary distance and duration for goats and sheep at Morais-Azibo SCI.

In the Morais-Azibo and Douro International SCI, climate conditions are more Mediterranean, affecting itinerary planning in a more significant way than in the remaining cases (Montesinho-Nogueira, Alvão-Marão and Montemuro). As sheep are very sensitive to high temperatures, in these hotter and drier areas, during summer, the flocks graze during the night. They set out to pasture before sunrise (between 4:00 a.m. and 5:30 a.m.) and remain in the fields only during the coldest period of the morning (they return to stables between 8:30 a.m. and 10:00 a.m.). Again, they graze at sunset (between 7:00 p.m. and 9:00 p.m.) for about 3-4 h. This is practiced during autumn until temperatures drop (Castro and Fernández-Núñez 2016). 
Studies performed at Montesinho-Nogueira SCI have also found an important annual variation in itinerary duration (lengths) which correlates with maximum daylight duration (Castro et al. 2009). For goats, the variation between August and December was 12.4 and $6.35 \mathrm{~h}$, respectively; for sheep, variation between July and December was 15.35 and 6 h (Castro 2004). Also at Alvão-Marão, SCI goat grazing itineraries were studied between August and October, and there were some variations found in the duration $(6-9.5 \mathrm{~h})$ and in the length $(7.2-13.7 \mathrm{~km})$ (Torres-Manso 2005).

The difference between daylight time and length of grazing itineraries suggests different patterns in goat and sheep requirements and management systems, showing sheep vulnerability to high temperatures. The length of sheep summer itineraries is higher than daylight time due to the long resting time during the hottest period of the day, being the only time of the year when sheep itineraries are longer than goat itineraries (Castro 2004). According to the same author, daylight time determines the duration of grazing itineraries, in both sheep and goat flocks. Nevertheless, the abundance of feeding resources and temperature pattern also play an important role in the duration of grazing itineraries.

\section{Interactions Between Grazing, the Shepherd and Nature Conservation}

Grazing systems are typical of mountain areas and are associated with livestock production based on sheep and goat native breeds. On their daily itineraries, flocks cross a variety of vegetation types, in different stages of their ecological succession, enjoying several food nutrient sources. This way, during the itinerary, animals can use natural or seminatural herbaceous plant communities, small-sized shrub communities, predominantly gorses (Ulex spp.), heaths (Erica spp.) and Pterospartum tridentatum, for more Continental-Atlantic locations, and laudanum (Cistus ladanifer) and rosemary (Lavandula spp.), for more Mediterranean locations.

Crossing different types of lands is made pursuant to unique rules and planning. The use of areas dominated by low shrubs is preferentially made by morning, while areas dominated by herbaceous plant vegetation or shrubs with younger sprouts are used preferentially in the evening. This pastoral planning is justified by the higher shrub vegetation freshness at early hours of the day, after a night period with higher levels of humidity and lower temperatures, and by the need to keep the flock well fed at the end of the day, so that animals can go through the night until the next day. It is worth mentioning that when the animals leave the stable in the morning, they have a greater appetite, therefore eating woodier material with lower nutritional values. Grazing itineraries are the result of the optimisation of several flock needs (feeding, rest, watering), structural variables (stable, water points and access location) and the land use restrictions (land interdiction due to municipal orders, ancient community rules, new forest plantations and temporary and permanent crops) (Castro 2008). 
During the process of interaction between the flock and the lands explored by the animals, the shepherd is a core element in the proper exploitation and management of natural resources and, consequently, in the sustainability and rationality of the whole model that highly depends on him as a land manager (Castro 2016). The outcome of this process is a permanent animal-vegetation-man interaction. By shepherding his flock, the shepherd takes advantage of natural vegetation, therefore obtaining tradable products without incurring in high expenses for the acquisition of production factors. This way of living is a demanding and not very attractive activity, which consists in shepherding the flock in a daily basis, without holidays, weekends or vacation, therefore being subject to daily social isolation. This is often made under adverse climate conditions, mainly in the mountains during the winter, with his meals, made in the fields, consisting in food brought from home, before leaving. A specific knowledge becomes necessary to keep and direct a flock in the conditions this activity is practiced, i.e. the shepherd's own know-how, gained over many years of learning (Barbosa and Portela 1999). For instance, goats leave the stable every day, and, other than that, they enjoy walking long distances when grazing (Pinto 1999).

Many of the areas covered are usually common land, mainly in the case of SCI of Alvão-Marão and Montemuro, although many north-eastern interior locations, namely, for the Montesinho-Nogueira, Morais-Azibo and Douro International SCI, are private areas, where the shepherd enjoys consuetudinary rights or even uses proper lands. Diversity concerning property ownership and usage may impair proper grazing management, as well as influence shepherd's freedom of actions. Pacheco (2002) highlights the infeasibility of the use of fences in common lands due to the imminence of conflicts with common neighbours, in addition to the absolute need of the shepherd's presence due to the danger of wolf attacks. However, nowadays, in the face of rural depopulation, there is a higher availability and diversity of grazing areas and a lower number of neighbours who allow that, with a lower chance of conflict, certain common areas are fenced. Land abandonment by its owners allows that current shepherds, via rental, increase their exploitation area and respective flocks. This has brought an intensification of production systems and a clear loss on the importance of shepherding. On the other side, it is worth highlighting that land depopulation leads to the abandonment of this activity and grazing decrease, which is leading to the shrub encroachment, therefore facilitating predator attacks and increasing the risk of fire.

In addition to his extenuating routine, the shepherd was, in a recent past, a frequent victim of social segregation (Pinto 1999). Under these circumstances, it is normal that the pursuit of this activity has decreased almost until its disappearance. There is however those who call for its conservation, notwithstanding its importance in rural area usage, many times justified when facing the argumentation of the higher quality of life when compared to the city.

According to Ribeiro (1998, in Pinto 1999), the history of pastoral activity has had some ups and downs, with the former concerning to times of depression and social instability and the latter regarding the general progress of calm and ordered peace. Martinho (1978) has mentioned that, despite the tendency for the abandonment 
of the pastoralism, people returning from the former colonies in 1975 "got hold" of sheep in Serra da Estrela and so did ex-immigrants from France and Germany.

This scenario of silvopastoral abandonment is not exclusive of Portuguese inner lands but a national and European problem which must be permanently reflected in terms of Common Agricultural Policy decision suitability in specific political, social and economic contexts of certain rural territories. In this scope, the European Shepherds Network Declaration was signed in 2015 which counts with more than 50 organisations that represent shepherds in 17 European countries, from Arctic, Atlantic, Mediterranean and Black Seas and Netherlands to the Alpine mountains (European Pastoralists Assembly 2015). These represent different cultures and grazing systems and claim a set of common interests in terms of silvopastoral activity defence and conservation. Among others, the following needs are highlighted:

- Recognition and valorisation of their cultural and social identity;

- Valorisation of their status and importance in territory management and planning;

- Creation of measures to ensure fair prices for their products;

- Own labelling as a guarantee for quality brands;

- Inclusion and representation in Common Agricultural Policy decision-making moments.

Among other things, that document reveals that current European shepherds have the capacity to plan and claim the valorisation of their status and role in territory management, in contrast with the former inexistence of awareness among traditional shepherds.

It is worth pointing out one of the foundations in which this declaration is based and that consists essentially in raising shepherds' awareness for their determining role in the scope of environment and nature conservation. According to them: "We protect the environment by preserving valued ecosystems where threatened plants and animals can survive, preventing the spread of shrubs and reducing the risk of fires. We use areas that are unsuited for and complementary to other forms of farming. Grazing helps store atmospheric carbon and mitigates climate change. We successfully manage natural resources, because we live from them, keeping them for future generations" (European Pastoralists Assembly 2015: 1).

The preservation of flora and fauna species and their habitats through grazing is important for the environment and nature conservation. It becomes clear that when landscapes are not protected against fires, their habitats and respective species are not either and carbon dioxide emissions rise. Torres-Manso et al. (2014) have shown that lands where grazing has significantly decreased or has almost disappeared are more vulnerable to fires.

In the mountain territories of Portugal's north and centre inner, landscape used by extensive grazing includes several priority habitats protected by the different sectorial plans of Natura 2000 network. The conservation of many of these habitats is strictly connected to shepherding, as the mat grass (Nardus stricta), junipers (Juniperus communis nana), meadows with Gentiana pneumonanthe and red-billed choughs (Pyrrhocorax pyrrhocorax), among others. 
Also, Mouquet et al. (2005) mention the importance of using periodical and moderate grazing strategies for the conservation of mountain meadows communities with Gentiana pneumonanthe and Maculinea alcon, an herbaceous plant and an Alcon blue butterfly, respectively, both classified as endangered species (IUCN 2014). However, these authors point out that intensive and continuous grazing may have an impact in the perpetuation of these species. According to Wallisdevries (2004), if the grazing intervention is not very intensive, the landscape heterogeneity promoted by the low pressure exerted by grazing may become a positive contribution to the perpetuation of Gentiana pneumonanthe and consequently of Maculinea alcon.

Pereira (2006) claims that the decline of the red-billed chough (Pyrrhocorax pyrrhocorax at the Natural Park of Alvão is essentially due to the abandonment of traditional extensive grazing systems. As its base diet is insects associated with livestock wastes, the abandonment of traditional grazing systems leads to the lack of concentrated food resources availability. Whitehead et al. 2005 have also shown the importance of partition promoted by selective grazing, given that wider areas facilitate the search for red-billed chough preys at the soil level.

According to Papanastasis et al. (1998), the long-term interaction between man and grazing in Mediterranean regions has promoted a remarkable contribution in the scope of ecosystem services, with the resilience to disturbances, fire prevention, biodiversity, hydrology and tourism being highlighted. The same author (2009) also mentions the role of grazing in ecosystem restoration, considering that proper management and handling may be a vital tool in silvopastoral areas, once these show an evolving trajectory from the presence of large herbivores to small ruminants. Thus, there is a degree of landscape modelling and species and habitat adaptability that must be considered and quantified from the decision-making point of view in the context of nature conservation measures.

\section{Silvopastoral System Adaptation to Current Times}

Native breeds of cattle, sheep and goats from the inner regions of north and centre of Portugal show a great affinity for classified areas, particularly for the territories specified in this study, with these integrating their farm of origin and current production areas. Despite the mutual relationships, animal headcount has decreased in the last decades as the number of farms, as confirmed in Fig. 12.2, following the decrease of the resident population ( -8 to $2 \%$ between 2001 and 2014) and the aging index tendency (from 161.3 to 247.1 , respectively) (INE, PORDATA n.d.).

In fact, this is a negative cycle dominated by a smaller and aging population and without qualifications reinforcing the lack of competitiveness of products gathered in farms with deficient size structure, where hard work is needed to overcome steep slopes and degraded or inaccessible trails for the herding. That situation contributes, in turn, to population decline and a further worsening of traditional silvopastoral system abandonment (European Parliament 2008; Torres-Manso et al. 2016). 


\begin{tabular}{|c|c|c|c|c|c|c|c|c|}
\hline \multicolumn{3}{|c|}{ Natura 2000 Network areas } & $\begin{array}{c}\text { Alvão- } \\
\text { Marão }^{(1)}\end{array}$ & $\begin{array}{l}\text { Montesinho- } \\
\text { Nogueira }^{(2)}\end{array}$ & $\begin{array}{l}\text { Morais- } \\
\text { Azibo }^{(3)}\end{array}$ & $\begin{array}{c}\text { Serra de } \\
\text { Montemuro }^{(4)}\end{array}$ & $\begin{array}{c}\text { Douro } \\
\text { Internacional }^{(5)}\end{array}$ & Total \\
\hline \multirow{6}{*}{ 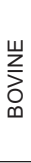 } & & 2009 & 7220 & 5163 & 2094 & 2985 & 9476 & 28947 \\
\hline & Livestock & 1999 & 9466 & 7121 & 1746 & 5788 & 11750 & 37870 \\
\hline & & 1989 & 11640 & 10166 & 2751 & 11275 & 10287 & 48108 \\
\hline & & 2009 & 1433 & 638 & 188 & 1074 & 531 & 5873 \\
\hline & Nr. Farms & 1999 & 2542 & 1441 & 399 & 2512 & 1121 & 10014 \\
\hline & & 1989 & 4272 & 2739 & 887 & 5531 & 1953 & 17371 \\
\hline \multirow{6}{*}{$\stackrel{\text { U }}{\precsim}$} & & 2009 & 1312 & 5992 & 2107 & 1548 & 4840 & 17808 \\
\hline & Livestock & 1999 & 1225 & 6783 & 2604 & 1657 & 5626 & 19894 \\
\hline & & 1989 & 871 & 6414 & 2077 & 1777 & 5053 & 18181 \\
\hline & & 2009 & 561 & 602 & 270 & 1523 & 451 & 5416 \\
\hline & Nr. Farms & 1999 & 561 & 744 & 264 & 1864 & 563 & 5995 \\
\hline & & 1989 & 805 & 853 & 206 & 2613 & 575 & 7041 \\
\hline \multirow{6}{*}{$\begin{array}{l}\text { U. } \\
\frac{\alpha}{\alpha} \\
\frac{\alpha}{\alpha} \\
\delta\end{array}$} & & 2009 & 1098 & 536 & 451 & 739 & 648 & 5481 \\
\hline & Unit & 1999 & 1327 & 750 & 455 & 1179 & 893 & 6603 \\
\hline & & 1989 & 1987 & 1458 & 690 & 1618 & 1511 & 9253 \\
\hline & & 2009 & 245 & 211 & 89 & 878 & 113 & 3545 \\
\hline & Nr. Farms & 1999 & 344 & $317 \mid$ & 90 & 1497 & 150 & 4397 \\
\hline & & 1989 & 691 & 769 & 147 & 2701 & 275 & 6572 \\
\hline
\end{tabular}

Included municipalities: (1) Mondim de Basto, Vila Pouca de Aguiar, and Vila Real; (2) Bragança, and Vinhais; (3) Macedo de Cavaleiros; (4) Castro Daire, Cinfães, Lamego, Resende; (5) Freixo de Espada à Cinta, Miranda do Douro, and Mogadouro.

Fig. 12.2 Evolution of livestock units and number of farms of Natura 2000 network areas from the north of Portugal (Source of data: INE 2011)

Different strategies have been developed aiming the adaptation of cattle farming systems to current constraints. An example is the return to ancient practices like "vezeira" (the shepherd take all the flock to graze in a certain area in turns) and the introduction of "alternate shepherds" (flocks kept by different shepherds, in different time periods), in response to the lack of available labour. Areas distant from the farm, once shepherded and cultivated, were abandoned, as common lands whose distances are no longer walkable, therefore originating the need to obtain alternative food resources. Such resources are found in lands near residences - with many of these lands having been given for shrub control - or are purchased from external sources.

The use of factors in production that are external to the farm is bringing the grazing and extensive production systems closer to intensive livestock production, with consequent increase in production costs and profitability losses. The autonomy, typical of such traditional systems, is therefore somehow affected, having a negative impact in sustainability (Marta-Costa and Costa 2010).

According to several authors (Esquivel 1998; Masera et al. 2000; Marta-Costa 2010), the definition of a sustainable farming system is based on productivity, reliability, resilience, adaptability, equity and self-resilience, framed in the interaction between economic, social and environmental dimensions. The economic dimension of sustainability is important because it influences the activity's survival and farmers' permanence in rural areas which is essential for protecting the environment and preserving both the landscape and its natural resources (Masera et al. 2000; CEC 2001; Fernandes and Woodhouse 2008; Marta-Costa 2010; Marta-Costa and Costa 2010; Marta-Costa et al. 2012). In Table 12.2, some of the critical points negatively affecting sustainability of silvopastoral systems developed in the mountain areas of Portugal are summarised, which dominate the Natura 2000 network sites of the country. 
Table 12.2 Critical points negatively affecting the silvopastoral systems sustainability of Natura 2000 network SCI of Portugal

\begin{tabular}{|c|c|c|}
\hline \multicolumn{3}{|l|}{ Dimension } \\
\hline Economical & Social & Environmental \\
\hline $\begin{array}{l}\text { Low system } \\
\text { profitability }\end{array}$ & Absence of workforce & Lack of forest management \\
\hline $\begin{array}{l}\text { Low production } \\
\text { efficiency }\end{array}$ & Laborious work & Forest abandonment \\
\hline $\begin{array}{l}\text { Very reduced livestock } \\
\text { per farm }\end{array}$ & Lonely job & $\begin{array}{l}\text { Predominance of non-native } \\
\text { forest species in some areas }\end{array}$ \\
\hline $\begin{array}{l}\text { Subsidy-dependent } \\
\text { systems }\end{array}$ & Population high aging rate & Villages dirty due to animal waste \\
\hline $\begin{array}{l}\text { No valorisation of farm } \\
\text { products }\end{array}$ & Farmers low education levels & $\begin{array}{l}\text { Absence of paths or inaccessible } \\
\text { paths for the shepherd }\end{array}$ \\
\hline $\begin{array}{l}\text { Lack of monthly fixed } \\
\text { salary }\end{array}$ & $\begin{array}{l}\text { Absence of descendants to } \\
\text { continue the activity }\end{array}$ & $\begin{array}{l}\text { Evolution of used agricultural } \\
\text { area occupation }\end{array}$ \\
\hline $\begin{array}{l}\text { Production input high } \\
\text { prices }\end{array}$ & $\begin{array}{l}\text { Low appreciation of agro- } \\
\text { livestock social activity }\end{array}$ & Landscape in transition \\
\hline $\begin{array}{l}\text { Difficulties in selling } \\
\text { products }\end{array}$ & High activity abandonment rates & \\
\hline $\begin{array}{l}\text { Lack of organisation of } \\
\text { the entire row }\end{array}$ & $\begin{array}{l}\text { Land structure (high } \\
\text { fragmentation and steep slopes } \\
\text { areas) }\end{array}$ & \\
\hline $\begin{array}{l}\text { Absence of accounting } \\
\text { records }\end{array}$ & Poor housing conditions & \\
\hline Low soil quality & & \\
\hline
\end{tabular}

Source: Adapted from Marta-Costa et al. (2012) and Torres-Manso et al. (2016)

Despite the different ways of maintaining and adapting cattle farming, there are obvious consequences arising from current production techniques. Some of them include the biomass accumulation because of pastoralism decrease and changes in the occupation of the utilised agricultural area (UAA), which is evolving towards being gradually occupied by permanent pasture (Fig. 12.3). As a result, the landscape mosaic is changed with the promotion of landscape homogeneity which contributes to less biodiversity as pointed out in previous sections.

Social aspects imply changes in systems and in the surrounding environment, but there are other retrains from the economical point of view originating new contexts which promote paths to future systems (Fig. 12.4). Currently, there has been an increase in input prices and a constancy in output prices originating profitability loss and demotivation for the practice of this activity. Associated with this situation is the higher attractiveness of urban centres. Although the occasional phenomenon of "return to the fields" due to financial reasons, there is the need to develop some mechanisms capable of fixating economic activities in rural mountain areas and compensate its outputs. These activities support production systems required not only for food production and other raw materials but are also essential for ecosystems, biodiversity and landscape maintenance as well as to retain people in the territory and therefore prevent the increase of abandoned areas (Table 12.3). 


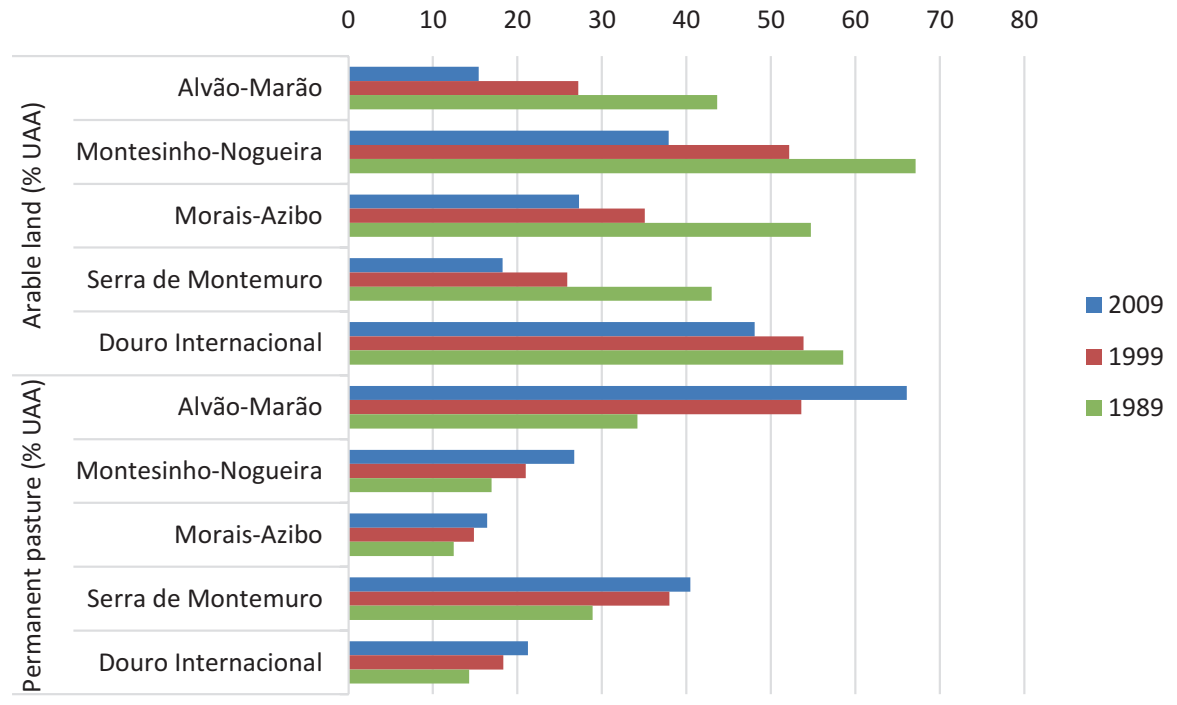

Fig. 12.3 Evolution of UAA occupation in studied Natura 2000 network areas, between 1989 and 2009 (Source of data: INE 2011)

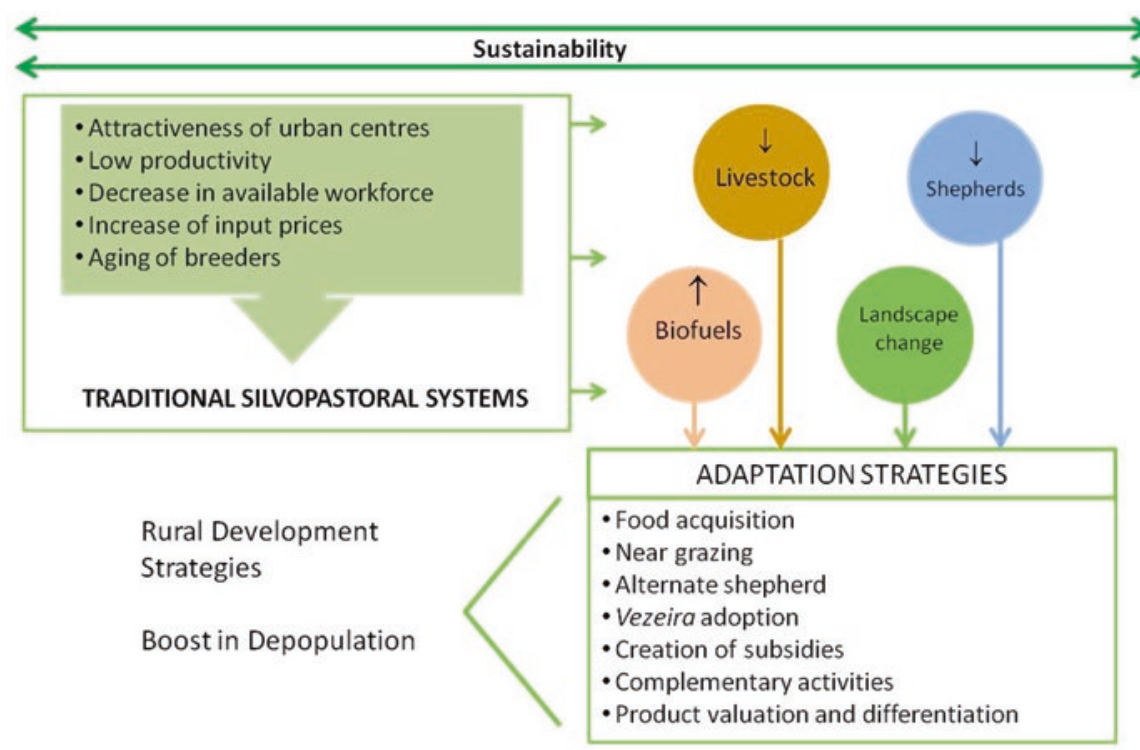

CHANGE IN SILVOPASTORAL SYSTEMS

Fig. 12.4 Silvopastoral systems adaptation to current constraints for studied Natura 2000 network areas (Source: Own elaboration) 
Table 12.3 Critical points positively affecting current silvopastoral systems sustainability of Natura 2000 network SCI of Portugal

\begin{tabular}{|c|c|c|}
\hline \multicolumn{3}{|l|}{ Dimension } \\
\hline Economical & Social & Environmental \\
\hline Silvopastoral systems: & Silvopastoral systems: & Silvopastoral systems: \\
\hline $\begin{array}{l}\text { Are a main source of revenue } \\
\text { for family farms }\end{array}$ & $\begin{array}{l}\text { Allow self-employment } \\
\text { creation }\end{array}$ & $\begin{array}{l}\text { Contribute to the maintenance and } \\
\text { valuation of areas with environmental } \\
\text { interest }\end{array}$ \\
\hline $\begin{array}{l}\text { Produce high-quality certified } \\
\text { products ensuring food safety } \\
\text { health and hygiene standards }\end{array}$ & $\begin{array}{l}\text { Allow to obtain food for } \\
\text { self-consumption }\end{array}$ & $\begin{array}{l}\text { Their several functionalities provide } \\
\text { biodiversity and contribute to } \\
\text { ecosystem conservation }\end{array}$ \\
\hline $\begin{array}{l}\text { Have low production costs due } \\
\text { to the high rusticity of native } \\
\text { breeds }\end{array}$ & $\begin{array}{l}\text { Their products safe } \\
\text { which provides a higher } \\
\text { consumer trust level }\end{array}$ & $\begin{array}{l}\text { Are fundamental to the conservation } \\
\text { of indigenous breeds (some of which } \\
\text { are endangered) }\end{array}$ \\
\hline $\begin{array}{l}\text { Have low (but growing) input } \\
\text { dependence }\end{array}$ & $\begin{array}{l}\text { Contribute to the } \\
\text { maintenance of rural } \\
\text { communities }\end{array}$ & $\begin{array}{l}\text { Are based on rational agro-livestock } \\
\text { management (better adaptation of } \\
\text { agrarian activities to edaphoclimatic } \\
\text { conditions) }\end{array}$ \\
\hline $\begin{array}{l}\text { Are based on farm's several } \\
\text { functionalities }\end{array}$ & $\begin{array}{l}\text { Provide wellbeing and } \\
\text { better life quality }\end{array}$ & $\begin{array}{l}\text { Reduce shrub encroachment and fire } \\
\text { risk }\end{array}$ \\
\hline $\begin{array}{l}\text { Are supported by community } \\
\text { measures }\end{array}$ & & Contribute to the landscape mosaic \\
\hline \multicolumn{3}{|l|}{$\begin{array}{l}\text { Contribute to valuation of } \\
\text { abandoned areas }\end{array}$} \\
\hline \multicolumn{3}{|l|}{$\begin{array}{l}\text { Are an alternative economic } \\
\text { activity }\end{array}$} \\
\hline $\begin{array}{l}\text { Reduce costs on fire } \\
\text { prevention }\end{array}$ & & \\
\hline
\end{tabular}

Source: Adapted of Marta-Costa et al. (2012) and Torres-Manso et al. (2016)

In response and as part of agricultural or rural development policies, some measures for financial support have been developed and granted directly to farms by means of subsidies (agro-environmental measures, compensatory allowances and others). Other support measures focus on valuation and differentiation of obtained products, by making specific labels (PDO, Protected Designation of Origin; PGI, Protected Geographical Indication; TSG, Traditional Specialities Guaranteed; biological agriculture; production and integrated protection) originating increases in sale prices. Further measures have converged to the diversification of economic activities (different types of tourism, handicraft, innovation in market transformation and access), focusing on the complementarity of income sources to move into to more self-sufficient and viable systems in the long run. Thus, in many places, the effect of such practices is still not at the desired levels, not being sufficient to ensure positive evolutional trends for rural population and effective livestock in Portugal (Marta-Costa and Silva 2016).

There are however sufficient conditions to change practices in terms of traditional farming systems, focusing on their adaptation to environmental and socioeconomic impulses, when seeking and/or trying to maintain its sustainability (Fig. 12.4), reflecting themselves in the several territorial dimensions and its biodiversity. 


\section{Final Considerations}

The classified mountain areas are geographically peripheral and difficult to access; moreover they have adverse edaphoclimatic and agroecological conditions and are in a disadvantage from a productive, economic and social point of view. However, over the centuries, human intervention through activities such as silvopastoralism shaped these areas to create habitats with high conservation interest. The negative evolution trend of the rural population and livestock population since the middle of the last century puts at risk the result of the mutually beneficial relationship between human presence, socioeconomic development of the territories and the preservation of the environment in rural areas. This situation is of specific relevance in classified areas of the Natura 2000 network, namely, in the SCI of Douro Internacional, Montesinho-Nogueira, Morais-Azibo, Alvão-Marão and Serra de Montemuro.

It is evident that the interaction between the shepherd, animal and the territory promotes benefits in landscape management and in the biodiversity conservation. This makes shepherds and pastoral systems that they implement real regulators and conservation agents, making evident the need to promote adaptations in the practiced production systems and within the associated ways of life, to make these activities more attractive, especially for the younger.

Different strategies, framed in policy measures, have been developed to reverse the downward trend of socioeconomic and environmental indicators in mountain areas both in general and in classified areas. However, its effects appear to be below from the desired, despite its contribution to the mitigation of the observed reality. At the same time, the natural adaptation of traditional silvopastoral systems to the new environmental and socioeconomic stimuli is aimed at seeking and/or trying to maintain its sustainability, reflecting themselves in the several territorial dimensions and its biodiversity.

Acknowledgments This work is supported by European Structural and Investment Funds, FEDER component, through the Operational Competitiveness and Internationalization Programme (COMPETE 2020) [Project No. 006971 (UID/SOC/04011)], and national funds, through FCT, Portuguese Foundation for Science and Technology under project UID/SOC/04011/2013.

\section{References}

Aguiar C, Torres-Manso F, Corte-Real J, Ferreira L, Pacheco F, Castro M (2015) Visitas técnicas: guia de campo da XXXVI Reunião de Primavera da SPPF. In: XXXVI Reunião de Primavera: as pastagens e o pastoreio em áreas de Montanha. Vila Pouca de Aguiar, pp 43-54

Almeida AMSF, Moura PVSV (1992) The relationship of forest fires to agro-forestry and socioeconomic parameters in Portugal. Int J Wildland Fire 2:37-40

Barbosa JC, Portela J (1999) The grazing in the system of exploitation of sheep in Trás-os-Montes. Minutes of the Conference: Montemuro the latest route of transhumance, Viseu

Castro M (2004) Análisis de la interacción vegetación-herbivoro en sistemas silvopastorales basados en Quercus pyrenaica. Ph.D. Thesis, Universidad de Alcalá de Henares, Alcalá de Henares 
Castro M (2008) A utilização dos pequenos ruminantes na prevenção dos incêndios rurais: estratégia pró-activa de promoção silvopastoril. In: Moreira MB, Coelho IS (coords) (eds) A silvopastorícia na prevenção dos fogos rurais. ISA Press, Lisbon, pp 159-175

Castro M (2016) Sistemas de produção animal em regiões de montanha em Portugal. In: Azevedo JC, Cadavez V, Arrobas M, Pires J (eds) Sustentabilidade da Montanha Portuguesa: Realidades e Desafios. CIMO/Instituto Politécnico de Bragança, Bragança

Castro M, Castro JF (2003) Ocupação tradicional do território e os novos modelos de utilização do espaço. In: Rodrigues O (eds) Futuro dos Territórios Rurais numa Europa Alargada. Actas of the V Colóquio Hispano-Português de Estudos Rurais, Instituto Politécnico de Bragança, Bragança, 23-24 Oct 2003

Castro M, Fernández-Núñez E (2016) Seasonal grazing of goats and sheep on Mediterranean mountain rangelands of northeast Portugal. Livest Res Rural Dev 28(5):1-13

Castro M, Castro J, Esteves A, Teixeira A, Gómez Sal A (2000) Les parcours annuels des troupeaux d'ovins dans la région de montagne de Trás-os-Montes e Alto Douro, au Portugal. In: Guessous F, Rihani N, Ilham A (eds) Livestock production and climatic uncertainty in the Mediterranean, EAAP Publication 94. Wageningen Pers, Wageningen, pp 371-373

Castro M, Castro JF, Teixeira AC (2003) Caracterização do sistema de pastoreio de percurso no nordeste de Portugal. Revista Portuguesa de Zootecnia X(2):95-105

Castro M, Castro JF, Gómez-Sal A (2009) The effect of environmental conditions in the duration of daily grazing itineraries of small ruminants in Northeast Portugal. Options Méditerr A 91:69-71

CEC (Commission of the European Communities) (2001) Commission Regulation (EC) N. ${ }^{\circ}$ 1837/2001 of 10 September 2001 amending Regulation (EEC) N. ${ }^{\circ} 2237 / 77$ on the form of farm return. In: Official Journal of European Communities L 255, 24.9.2001, 51 pp

EEA (European Environment Agency) (2012) Protected areas in Europe - an overview. EEA Report No 5/2012. European Environment Agency, Copenhagen. http://www.eea.europa.eu/ publications/protected-areas-in-europe-2012/

Esquivel CEG (1998) Evaluation of sustainability in dairy cattle production systems. Ph.D. thesis, University of London, London

European Parliament (2008) Report on the future of the sheep/lamb and goat sector in Europe, $14 \mathrm{p}$

European Pastoralists Assembly (2015) European shepherds network declaration, Koblenz. http:// shepherdnet.eu/?newsletter=koblenz-ehrenbreitstein-declaration

Fernandes L, Woodhouse P (2008) Family farm sustainability in southern Brazil: an application of agri-environmental indicators. Ecol Econ 66:243-257

INE (Instituto Nacional de Estatística) (2011) Recenseamento Agrícola 2009. INE, Lisbon. https:// www.ine.pt/

INE/PORDATA (n.d.) BI das Regiões. PORDATA, Boticas. www.pordata.pt/Municipios

IUCN (International Union for Conservation of Nature) (2014) The IUCN Red List of Threatened Species. Version 2014.3. www.iucnredlist.org

Kukkala AS, Arponen A, Maiorano L, Moilanen A, Thuillre R, Toivonene T, Zupan L, Brotons L, Cabeza M (2016) Matches and mismatches between national and EU-wide priorities: examining the Natura 2000 network in vertebrate species conservation. Biol Conserv 198(6):193-201

Mancilla-Leytón J, Mejías R, Vicente A (2013) Do goats preserve the forest? Evaluating the effects of grazing goats on combustible Mediterranean scrub. Appl Veg Sci 16:63-73

Marta-Costa AA (2010) Sustainability study for the rearing of bovine livestock in mountainous zones. New Medit IX(1):4-12

Marta-Costa AA, Costa H (2010) The economic crisis and agrarian sustainability: weaknesses and potentialities. Case study on goat farms. In: Coudel D, Soulard H (eds) Proceedings of symposium innovation and sustainable development in agriculture and food - ISDA (June 28-July 1, 2010). Cirad, INRA, SupAgro, Montpellier, 11p

Marta-Costa A, Silva E (2016) Global overview of the rural development programme: the mainland Portugal case-study. In: Wilcox A, Vinall S (eds) Social and technological transformation of farming systems: diverging and converging pathways - 12th European IFSA Symposium, Harper Adams University, Newport, 12-15 July 2016. http://www.harper-adams.ac.uk/events/ ifsa-conference/papers/5/5.3\%20Marta-Costa.pdf 
Marta-Costa A, Torres-Manso F, Tibério L (2012) Sustainability diagnosis of an agroforestry system. Reg Sci Inq J IV(2):111-124

Martinho A (1978) O Pastoreio e o queijo da Serra. Serviço Nacional de Parques, Reservas e Património Artístico, Lisbon, 125p

Masera Ó, Astier M, López-Ridaura S (2000) El Marco de Evaluación MESMIS. In: Masera O, López-Ridaura S (eds) Sustentabilidad y Sistemas Campesinos. GIRA A. C. - Mundi Prensa PUMA, México, pp 13-44

Mather AS, Pereira JMC (2006) Transição Florestal e Fogo em Portugal. In: Pereira JS, Pereira JM, Rego FC, Silva JM, Silva TP (eds) Forest Fires in Portugal: characterization. Impacts and Prevention. ISA/Press, Lisbon, pp 257-282

Mouquet N, Belrose V, Thomas JA, Elmes GW, Clarke RT, Hochberg ME (2005) Conserving community modules: a case study of the endangered Lycaenid butterfly Maculinea Alcon. Ecology 86(12):3160-3173

Pacheco F (2002) Des systèmes caprins et ovins traditionnels en crise: une menace pour les zones de montagne de la région d'Entre Douro e Minho au Portugal. Options Méditerr B 39:67-74

Papanastasis VP (2009) Restoration of degraded grazing lands through grazing management: can it work? Restor Ecol 17(4):441-445

Papanastasis VP, Enne G, Dubost M, Seligman N, Talamucci P, Liacos L (1998) Conclusions and recommendations. In: Papanastasis VP, Peter D (eds) Ecological basis of livestock grazing in Mediterranean. European Commission, Luxembourg, pp 343-344

Pereira CSF (2006) Ecologia e Caracterização do Núcleo de Gralha-debico-vermelho (Pyrrhocorax pyrrhocorax, Linnaeus 1758) no Parque Natural do Alvão. Relatório Final de Estágio, University of Trás-os-Montes e Alto Douro, Vila Real

Pinto RLA (1999) The profile of the shepherd. Internship report, University of Trás-os-Montes e Alto Douro, Vila Real

Portela J (1988) Rural household strategies of income generation. A study of North-Eastern Portugal, 1900-1987. Ph.D. thesis, University of Wales, Wales

Ruiz-Mirazo J, Robles A (2012) Impact of targeted sheep grazing on herbage and holm oak saplings in a silvopastoral wildfire prevention system in south-eastern Spain. Agrofor Syst 86:477-491

Sousa F, Sanchéz L (2009) Mirandesa, Associação dos Criadores de Bovinos de Raça Mirandesa, Miranda do Douro

Teles AN (1970) Os lameiros de montanha do norte de Portugal. Subsídios para a sua caracterização fitossociológica e química. Separata da Agronomia Lusitana XXXI (I - II): 141

Telo da Gama L (Cood.) (2004) Recursos Genéticos Animais em Portugal. Relatório Nacional, INIAP / FAO, pp 53

Torres-Manso F (2005) O Pastoreio e a Protecção dos Ecossistemas Florestais. Ph.D. thesis, University of Trás-os-Montes e Alto Douro, Vila Real

Torres-Manso F (2015) Pastoreio em Territórios de Montanha. Newsletter No. 6 Sociedade Portuguesa de Pastagens e Forragens

Torres-Manso F, Fernandes P, Pinto R, Botelho H, Monzon A (2014) Regional livestock grazing, human demography and fire incidence in the Portuguese landscape. For Sys 23(1):15-21

Torres-Manso F, Marta-Costa A, Tibério L, Pinto R (2016) Traditional grazing systems in the north of Portugal: a social, economic and environmental approach. In: Dagar JC, Tewari JC (eds) Agroforestry research development. Nova Publishers, New York, pp 425-446

Wallisdevries MF (2004) A quantitative conservation approach for the endangered butterfly Maculinea alcon. Conserv Biol 18(2):489-499

Whitehead S, Johnstone I, Wilson J (2005) Chough Pyrrhocorax pyrrhocorax breeding in Wales select foraging habitat at different spatial scales. Bird Study 52:193-203 